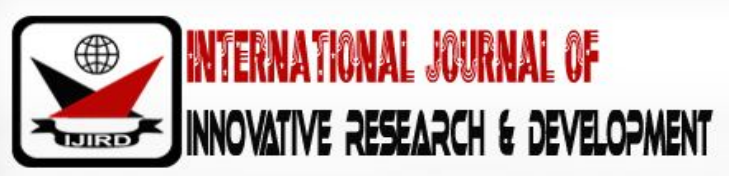

ISSN 2278 - 0211 (Online)

\section{Impact of Supplier Enablement on E-Procurement Implementation: A Survey of the Multinational Tea Companies}

\author{
Evalyne Chepkemoi \\ Bomet University College, Kenya
}

\begin{abstract}
:
Electronic procurement is the use of electronic computer systems to manage the entire procurement process. The success of eprocurement is equally dependent of the success of the supplier which calls for the need to maximize on supplier participation while minimizing on supplier disruption, therefore the need for supplier enablement. The purpose of this study is to assess the impact of supplier enablement on the implementation of e-procurement by multinational tea companies in Kericho County. The target population was the heads of procurement departments and two employees drawn from each of the three companies. A cross-sectional survey was used with sample 63 responded. Questionnaires were used as the instrument for collecting primary data and later analyzed using the following regression analysis $=\alpha+\beta 1 X 1$.According to data findings; the independent variable supplier enablement was found to have correlation coefficients of 0.512 with the implementation of eprocurement among the multinational tea companies involved in the study. Conclusions are that the lack of supplier enablement was found to be key impediment to the implementation of e-procurement. Recommendations are that full adoption and implementation is a necessity that can only be achieved through a collaborative effort among the key players specific field. It is necessary that the involved tea firms should look at a means of working together as a team and build systems that will allow easier e-procurement functionality.
\end{abstract}

Keywords: Supplier Enablement, E-Procurement, Bomet, Kenya

\section{Introduction}

\subsection{Background of the Study}

E-Procurement is the business-to-business purchase and sale of supplies and services through the Internet as well as other information and networking systems. The successful implementation of e-procurement increases efficiency, effectiveness and productivity in an organization. Suppliers who are the driving forces in the e-procurement success require enablement because when the Suppliers are Enabled, the organization benefits in the following ways; it Produces a higher percentage of supplier participation, it reduces the transaction costs and errors, Shortens the time period for measurable returns on investment and the Suppliers also gets to enjoy full technical capability without the usual high technical barriers, a minimizes the startup fee, lowers the cost of ownership and enables the use solution with multiple customers(Hills, 2010)

Aberdeen Group, (2007) defines Supplier enablement as the process of connecting suppliers to an enterprise's supply chain. This process if properly undertaken benefit the organization by ensuring that companies meet customer demand by procuring materials at the right speed for the right cost. A study by Aberdeen group (2007) study shows the main objective of supplier enablement is to enable business to business e-commerce with suppliers, to reduce procurement operating costs, to reduce accounts payable operating costs, to improve quality of supplier information, to increase spend under management and increase savings costs from lower payments respectively.

\subsubsection{Multinational Tea Companies}

E-Procurement plays a major role in processing and export of tea, which is necessary for organizations success. Kenya is Africa's leading tea producer and fourth in the world behind India, China and Sri Lanka. Black tea is the country's leading agricultural foreign exchange earner. The tea industry is divided between small farms and large estates. Tea is the country's leading foreign exchange earner at the moment, with export earnings standing at about Kshs 110 billion up from Kshs 33 billion in 2003, a 230\% increase. Its output accounts for about 11\% of agriculture's share of Kenya's Gross Domestic Product 
(GDP). There are three multinational tea companies in Kericho County, Kenya, with Unilever tea Kenya ltd (UTKL) owning a total of 8,250 hectares under tea while James Finlay's is the second with 5,554 hectares of tea. KHRC (2008) Williamson tea is the next which is a family owned business. Attached is a list of multinational tea companies in Kenya, Kericho County.

\subsection{Research Hypothesis}

The research hypothesis was given by;

There no significant effect of supplier enablement on the implementation of e-procurement.

\section{Literature Review}

\subsection{Overview of Supplier Enablement}

According to Tan, Felix \& Ter (2010), successful e-procurement system is required to have suppliers willing and able to trade electronically. A study conducted by the AGIMO (2005), showed that supplier adoption is important to the overall success of an e-procurement program. The study concluded that the more suppliers in the system, the more inclined buyers will be to use it. If suppliers are not correctly involved, then a low adoption rate can constrain users from leveraging the full associated capabilities from e-procurement solutions.

The lack of a critical mass of suppliers accessible through the organization's e-procurement system might limit the network effects that underlie these technologies, delaying the acceptance and adoption of the solution Paulo (2009). According to a study by Lin, Huang, Jalleh \& Tung (2010) about the adoption of e-commerce by the health care organizations in Australia, there were complains about loss of interpersonal relationships with suppliers and customers via the use of e-procurement systems.

Therefore, those organizations that had fewer problems in adopting and implementing e-procurement systems were those that had better communication with key stakeholders throughout the entire supply chain and had listened to their concerns. Several interview participants also mentioned that having effective supply chain management in their organizations was not good enough. Benefits only would come about if these management processes could be extended to the suppliers. Some participating health care organizations had some difficulties or simply failed to integrate their e-procurement system with other functions throughout the supply chain.

Most did not have an IT strategy to integrate their e-commerce with other systems. For example, many health care organizations, such as hospitals and pharmaceutical companies, had purchased their own IT/ e-procurement systems; therefore, it was not surprising to see that their systems within the same organizations were unable to communicate, let alone between hospitals or different health care organizations across the entire supply chain. Lin et al (2010)

Vendor/ supplier support also can play a critical role in successful adoption and implementation of e-procurement systems for organizations. Case study results revealed that while e-procurement systems' vendors/suppliers were closely involved in the decisions leading to funding of the project, there was a general lack of interest from the vendor once the systems were purchased and implemented. For example, a significant number of organizations mentioned that it often was difficult to get the various e-procurement software and hardware vendors/ suppliers and external consultants to resolve software problems. Effective coordination and communication among the organizations, various vendors/suppliers, and external consultants were noted as being essential (Lin et al, 2010)

In the early days of e-procurement, buying enterprises and solution providers underestimated the time, effort, and resources required to enable suppliers to transact business electronically. Though tremendous progress has been made in supplier enablement, all involved parties - end users, suppliers, and solution providers - continue to work to make enablement as simple and cost effective as possible. A survey by Aberdeen group (2005) identified various approaches applicable in supplier enablement with their benefits and trade-offs as buyer managed approach, supplier managed approach, Supplier network approach and Alternative approach.

Buyer-managed approach uses aggregated catalogue of suppliers and the buying organization has control. The buyer incurs all the cost and has limited supplier population. Supplier- Managed approach is the where buyers access product information through the supplier's site. Here, the usability of the product information can be limited and the buying organization loses control. The advantage is that Leverages industry standard XML schemas to provide maximum control over product data.

Supplier network approach is where Buyers pay subscription fee for access to customize version of suppliers catalog. The advantage is that it provides Single point of integration for product and transaction content management. Not all suppliers in the network are relevant to all buying organizations. Another approach is the Alternative approach where the Supplier portals Smart Forms. It is best for relatively complicated, non-catalog items and does not provide the inherent benefits of machine-to-machine communication.

Individual end users and entire business units naturally resist any change in business processes that takes away buying power and buying flexibility. Over the past few years, user adoption has increased at essentially the same pace as the increase in suppliers enabled. With more products and suppliers on the e-procurement system, users have less reason to try to circumvent the system. Still, end users report that several factors continue to hold back user adoption, including inadequate representation of spending categories within the system, inconsistent purchase requirements, procedures, and supply bases 
by site or region, and a lack of executive mandates or policies to drive adoption and system compliance. Best Practice enterprises have worked on user adoption for years, and many supply executives at these enterprises have become leading "sellers" of the e-procurement system to end users. Aberdeen group (2005)

\section{Methodology}

\subsection{Data Description of Survey Data}

This study employed descriptive research design to assess the impact of supplier enablement on e-procurement implementation in Kenya's tea industry. A Cross sectional census survey was conducted where both primary and secondary data were collected for the study. Questionnaires were self- administered on 21 individuals from each of the three multinational tea companies in Kericho County (The heads of procurement and stores department and employees).

\subsection{Model Specification}

The data was analyzed using quantitative techniques. Quantitative data was analyzed using descriptive statistics with the help of Statistical Packages for Social Sciences (SPSS) tool and presented inform of tables. Inferential statistics with the help of linear regression analyses tool was also used. The output was presented in graphs, charts and tables. The following linear regression analyses model was used to establish the extent at which supplier enablement effects of e-procurement implementation among Multinational tea companies in Kericho County, Kenya.

Equation 1: Regression Analyses Model

$\gamma=\alpha+\beta_{1} X_{1}$

Where:

$\gamma$ - Successful implementation of e-procurement, $\alpha$ - Constant, X1 - Cumulative scores for supplier enablement and $\beta 1$ Regression coefficient for supplier enablement. Interpretation was done based on the objectives of the study and the research questions.

\section{Results and Discussion}

\subsection{Supplier Enablement}

Concerning the extent to which supplier enablement was considered an impediment to effective implementation and use of e-procurement among the multinational tea companies in Kericho County.

\subsubsection{Supplier Enablement as a Challenge}

The recognition of whether supplier enablement was a challenge to e-procurement implementation received the following response:

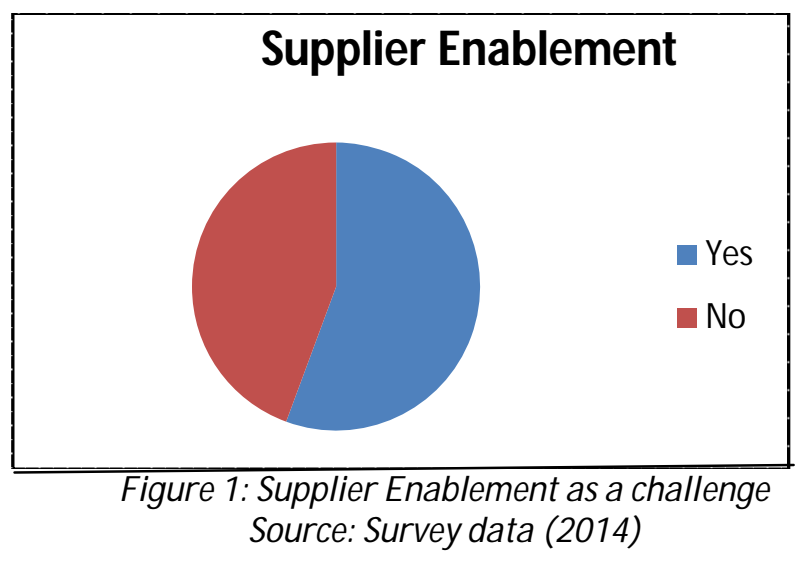

A majority of $55.6 \%$ indicated their acknowledgement of supplier enablement as a key challenge to the use of eprocurement. Only a small fraction $44.4 \%$ indicated otherwise.

\subsubsection{Supplier Enablement Challenges}

To establish the exact elements of the supplier enablement the hinders effective implementation of e-procurement, the respondents were also requested to indicate the specific components considered a challenge and the results are presented in table 1 below: 


\begin{tabular}{|c|c|c|}
\hline Value & Count & Percent \\
\hline Internet connection & 42 & $66.7 \%$ \\
\hline Lack of system integration & 35 & $55.6 \%$ \\
\hline Lack of trained personnel & 56 & $88.9 \%$ \\
\hline Lack of computers & 20 & $31.7 \%$ \\
\hline
\end{tabular}

Table 1: Supplier enablement challenges

Source: Survey data (2014)

Lack of trained personnel was rated as most impeding element with a rating of $88.9 \%$. This was followed by Internet connectivity to link supplier with $66.7 \%$. Lack of system integration was rated third with $55.6 \%$ and lack of computers and related hardware was given a rating of $31.7 \%$.

\subsubsection{Level to Which Supplier Enablement is a Challenge}

The extent to which each of the above elements were responded to in regard to the level they are considered a challenge are presented in Table 2 Below

\begin{tabular}{|l|l|l|l|l|l|}
\hline & \multicolumn{1}{|c|}{ Very High } & \multicolumn{1}{c|}{ High } & \multicolumn{1}{c|}{ Average } & \multicolumn{1}{c|}{ Low } & \multicolumn{1}{c|}{ Very Low } \\
\hline Internet connection & $35(55.56 \%)$ & $21(33.33 \%)$ & $3(4.76 \%)$ & $4(6.35 \%)$ & $0(0.00 \%)$ \\
\hline Lack of system integration & $23(36.51 \%)$ & $31(49.20 \%)$ & $5(7.94 \%)$ & $4(6.35 \%)$ & $0(0.00 \%)$ \\
\hline Lack of trained personnel & $41(65.08 \%)$ & $19(30.16 \%)$ & $2(3.17 \%)$ & $1(1.59 \%)$ & $0(0.00 \%)$ \\
\hline Lack of computers & $11(17.46 \%)$ & $26(41.27 \%)$ & $23(36.51 \%)$ & $3(4.76 \%)$ & $0(0.00 \%)$ \\
\hline
\end{tabular}

Table 2: Level to which supplier enablement is a challenge

Source: Survey data (2014)

Internet connectivity to facilitate supplier enablement was rated as a very high challenge by with mean of 4.381 and most of the respondent strongly agreed. Lack of systems integration was seen by majority of the respondents as a high hindrance (mean of 4.095). Lack of trained personnel to drive the supplier enablement process was seen by the highest obstruction to the implementation of e-procurement systems (mean of 4.5873). Lack of computers and related hardware to facilitate the enablement of suppliers through the use of e-procurement was seen be moderately higher than average challenge to implementation of e-procurement systems by multinational tea companies in Kericho County (mean of 3.7143)

\subsection{Regression Analysis}

To determine the extent and the contribution of supplier enablement to implementation of e-procurement among the multinational companies operating in Kericho County, liner regression analysis was performed with the level of implementation being the dependent variable while cumulative score of supplier enablement was taken as the independent variables.

$\gamma=\alpha+\beta_{1} X_{1}$

Where: $\gamma$ - Successful implementation of e-procurement, $\alpha$ - Constant, $\mathrm{X}_{1}$ - Cumulative scores for supplier enablement and $\beta_{1}$-Regression coefficient for supplier enablement

The outcome of the analysis were first examined to ensure that it does not violate the key requirements of regression analysis specifically existence of multi-co linearity among the variables. Person's correlation between the variables was as presented below:

\begin{tabular}{|c|c|c|c|}
\hline \multicolumn{2}{|c|}{} & $\begin{array}{c}\text { Supplier } \\
\text { Enablement }\end{array}$ & $\begin{array}{c}\text { Implementation of } \\
\text { E-procurement }\end{array}$ \\
\hline \multirow{2}{*}{ Supplier Enablement } & Pearson Correlation & 1 & $.512^{* *}$ \\
\cline { 2 - 4 } & Sig. (2-tailed) & & .000 \\
\cline { 2 - 4 } & $\mathrm{N}$ & 63 & 63 \\
\hline \multirow{2}{*}{$\begin{array}{c}\text { Implementation of E- } \\
\text { procurement }\end{array}$} & Pearson Correlation & $.512^{* *}$ & 1 \\
\cline { 2 - 4 } & Sig. (2-tailed) & .000 & 63 \\
\cline { 2 - 4 } & $\mathrm{N}$ & 63 & \\
\hline \multicolumn{2}{|c|}{$* *$ Correlation is significant at the 0.01 level (2-tailed). } \\
\hline
\end{tabular}

Table 3: Correlation between the independent and dependent variables

Source: Survey data (2014) 
The independent variable was found to have correlation coefficient of 0.512 , and the implementation of eprocurement among the multinational tea companies involved in the study. It was above 0.3, the recommended minimum indication of substantial correlation (Pallant, 2005).

\begin{tabular}{|c|c|c|c|c|c|}
\hline Model & R & R Square & $\begin{array}{c}\text { Adjusted R } \\
\text { Square }\end{array}$ & $\begin{array}{c}\text { Std. Error of the } \\
\text { Estimate }\end{array}$ & Durbin-Watson \\
\hline 1 & $.512^{\mathrm{a}}$ & .262 & .250 & .628 & 2.068 \\
\hline \multicolumn{5}{|c|}{ a. Predictors: (Constant), Supplier Enablement } \\
\hline \multicolumn{5}{|c|}{ b. Dependent Variable: Implementation of E-procurement }
\end{tabular}

Table 4: Coefficient of determination

The correlation coefficient between the independent variable was also examined and it was 0.512 . The R Square Value for the model was found to be 0.262 indicating that supplier enablement significantly explained $26.2 \%$ of the variance in the level of e-procurement implementation among the tea firms.

This is further supported with the study by Barcelo (1999) who identified supplier enablement Filipe (2009) as a challenge faced in the implementation of e-procurement.

\begin{tabular}{|c|c|c|c|c|c|c|}
\hline \multicolumn{2}{|c|}{ Model } & Sum of Squares & df & Mean Square & F & Sig. \\
\hline \multirow{3}{*}{1} & Regression & 8.533 & 1 & 8.533 & 21.626 & $.000^{\mathrm{b}}$ \\
\cline { 2 - 7 } & Residual & 24.070 & 61 & .395 & & \\
\cline { 2 - 6 } & Total & 32.603 & 62 & & \\
\hline \multicolumn{6}{|c|}{ a. Dependent Variable: Implementation of E-procurement } \\
\hline
\end{tabular}

Table 5: ANOVA

The ANOVA indicate there existed significant relationship between supplier enablement and implementation of Eprocurement.

\begin{tabular}{|c|c|c|c|c|c|c|c|c|}
\hline & \multirow[t]{2}{*}{ Model } & \multicolumn{2}{|c|}{$\begin{array}{l}\text { Unstandardized } \\
\text { Coefficients }\end{array}$} & \multirow{2}{*}{$\begin{array}{c}\begin{array}{c}\text { Standardi } \\
\text { zed } \\
\text { Coefficien } \\
\text { ts }\end{array} \\
\text { Beta }\end{array}$} & \multirow[t]{2}{*}{$t$} & \multirow[t]{2}{*}{ Sig. } & \multicolumn{2}{|c|}{$\begin{array}{l}\text { Collinearity } \\
\text { Statistics }\end{array}$} \\
\hline & & $\bar{B}$ & $\begin{array}{c}\text { Std. } \\
\text { Error }\end{array}$ & & & & $\begin{array}{c}\text { Tolera } \\
\text { nce }\end{array}$ & VIF \\
\hline \multirow[t]{2}{*}{1} & (Constant) & 1.946 & .466 & & 4.180 & .000 & & \\
\hline & $\begin{array}{c}\text { Supplier } \\
\text { Enablement }\end{array}$ & .533 & .115 & .512 & 4.650 & .000 & 1.000 & 1.000 \\
\hline
\end{tabular}

Table 6: Regression Model Fit

Source: Survey data (2014)

From the results lack of supplier enablement was found to make the contribution to the challenges in implementation of e-procurement with a beta of 0.533 and a significant contribution being $(\mathrm{sig}<0.05)$. Thus it was evident thatlack of supplier enablement was of key contribution to impediments to implementation of e-procurement among multinational tea companies operating in Kericho County.

These findings are supported by several researchers who identified that Suppliers do not fit into organizational plans or may want to do things their way. This may be because organizational processes and systems do not match those used by most of their other customers or because organizational business is insufficient to justify organization's investment in the system. 


\section{Conclusion and Recommendation}

\subsection{Conclusion}

Having set out to evaluate the extent of supplier enablement being an impediment to the implementation of eprocurement among multinational tea firms within Kericho County and analyzed the finding, the researcher made the following conclusion in line with the objectives of the study. Implementation of e-procurement systems remains a key enabler of successful execution of procurement functions especially for firms that must engage in regional and international national procurement. Full adoption and implementation is a necessity that can only be achieved through a collaborative effort among the key players specific field.

\subsection{Recommendation}

It is the researcher's recommendation that both the tea firms should look at a means of working together as a team and build systems that will allow easier e-procurement functionality. More so each party must solicit the support of the other either by sharing related costs, IT platform and resources. Despite internet connectivity being currently a challenge it may not last due to the advent of the fiber optic cable spreading across the country. This will be a key asset to eliminating most of the challenges associated with supplier enablement.

\section{References}

i. Aberdeen Group. (2007). Supplier enablement. A Harte-Hanks Company, pp 1-20.

ii. AGIMO, (2005). E-Government online services. Australian Government Information Management Offices.

iii. KHRC (2008), A Comparative Study of the Tea Sector in Kenya: A Case Study of Large Scale Tea Estates, A Report by Kenya Human Rights Commission, Kenya,

iv. Lin, C., Huang, Y.-A., Jalleh, G., Liu, Y.-X. and Tung, M.-L.,. (2010). An exploratory study of factors affecting adoption and implementation of B2B e-commerce in Australian health care organizations. International Journal of Electronic Commerce, Vol. 1, No. 2, pp. 77-96.

v. Pallant, J. (2005). SPSS survival manual: A step by step guide to data analysis using SPSS for Windows (Version 12) (2nd ed.). New York: McGraw-Hill.

vi. Paulo, A. \& Filipe, A. (2009), Electronic Procurement: Dealing with Supplier Adoption: Management Information Systems Management, University of Lesbon, Palestine. 